\title{
Clinical reasoning in nursing: teaching strategies and assessment tools
}

\author{
Raciocínio clínico em enfermagem: estratégias de ensino e instrumentos de avaliação
}

Razonamiento clínico de la enfermería: estrategias de la enseñanza e instrumentos de evaluación

\section{Emília Campos de Carvalho', Ana Railka de Souza Oliveira-Kumakural", Sheila Coelho Ramalho Vasconcelos Morais"II}

\author{
' Universidade de São Paulo, Nursing School. Ribeirão Preto, São Paulo, Brazil. \\ "Universidade Estadual de Campinas, Nursing School. Campinas, São Paulo, Brazil. \\ I' Universidade Federal de Pernambuco, Department of Nursing. Recife, Pernambuco, Brazil.
}

How to cite this article:

Carvalho EC, Oliveira-Kumakura ARS, Morais SCRV. Raciocínio clínico em enfermagem: estratégias de ensino e instrumentos de avaliação. Rev Bras Enferm [Internet]. 2017;70(3):662-8. DOI: http://dx.doi.org/10.1590/0034-7167-2016-0509

Submission: 09-16-2016 Approval: 12-04-2016

\begin{abstract}
Objective: To present the concept and development of teaching strategies and the assessment tools regarding clinical reasoning for accurate practice. Method: This is a theoretical reflection based on scientific studies. Results: Comprehension of the essential concepts of the thought process and its articulation with the different teaching strategies and the assessment tools which has allowed presenting ways to improve the process of diagnostic or therapeutic clinical reasoning. Conclusion: The use of new strategies and assessment tools should be encouraged in order to contribute to the development of skills that lead to safe and effective decision making.

Descriptors: Education, Nursing; Clinical Decision-Making; Nursing Diagnosis; Cognition; Mental Processes.
\end{abstract}

\section{RESUMO}

Objetivo: Apresentar o conceito de raciocínio clínico, seu desenvolvimento, as estratégias para seu ensino e os instrumentos de avaliação para uma prática acurada. Método: Trata-se de uma reflexão teórica fundamentada em estudos científicos. Resultados: A compreensão dos conceitos essenciais do processo de pensamento e sua articulação com as diferentes estratégias de ensino e com os instrumentos de avaliação permitiram exemplificar meios de aprimorar o processo de raciocínio clínico diagnóstico ou terapêutico. Conclusão: A utilização de novas estratégias e instrumentos de avaliação deve ser estimulado para contribuir com o desenvolvimento das habilidades que culminam na tomada de decisão segura e eficaz.

Descritores: Educação em Enfermagem; Tomada de Decisão Clínica; Diagnóstico de Enfermagem; Cognição; Processo Mental.

\section{RESUMEN}

Objetivo: Presentar el concepto de razonamiento clínico, su desarrollo, las estrategias para su enseñanza y los instrumentos de evaluación para una práctica esmerada. Método: Se trata de una reflexión teórica fundamentada en estudios científicos. Resultados: La comprensión de los conceptos esenciales del proceso de pensamiento y su articulación con diferentes estrategias de enseñanza y con diversos instrumentos de evaluación, permitió ejemplificar medios para la mejoría del razonamiento clínico en el proceso del diagnóstico o en el terapéutico. Conclusión: Es necesario valerse de estrategias nuevas y de instrumentos de evaluación para estimular el desarrollo de habilidades que lleven a la toma de decisiones seguras y eficaces.

Descriptores: Educación en Enfermería; Toma de Decisión Clínica; Diagnóstico de Enfermería; Cognición; Proceso Mental. 


\section{INTRODUCTION}

Clinical reasoning in nursing is essential for a safe and effective care. However, it faces the challenge of finding teaching strategies and learning experiences to promote the development of this skill in the learner ${ }^{(1)}$.

The development of the ability to think, reason, use information to acquire knowledge, understand the world and make appropriate decisions starts from early childhood. These processes are learned uniquely through relationships, and are under the influence of the state of physical and emotional safety, the environment, individual potentialities, beliefs, standards and cultural aspects ${ }^{(2)}$.

The thought or intellect involves the mental operations of conceiving (forming and learning ideas about an object), judging (discrimination of the identity or diversity of two concepts) and reasoning (conclusion based on two or more previously known related judgments) $)^{(3)}$. Thus, nurses have to organize their thinking process in order to carry out the process of clinical reasoning.

In care practice, the thought process that leads to clinical reasoning must occur in all phases of the nursing process. In order to do this, the professional must: recognize cues/evidence about the situation investigated (consider the idea); recognize differences between the situation and a similar one (elaborate their judgment); conclude thinking based on two or more related judgments, previously known (reasoning) ${ }^{(3)}$. It is the nurse's responsibility to accurately interpret the human responses, in order to select appropriate interventions and evaluate the outcomes achieved ${ }^{(4)}$.

In this context, some questions about the development of clinical reasoning in nursing arise: What are the types of clinical reasoning? What are the teaching strategies adopted for the development of clinical reasoning? How to develop clinical reasoning for an appropriate practice? Searching for answers to these questions, the present text will address the concept, development and teaching strategies of clinical reasoning, as well as the tools for its evaluation.

\section{CLINICAL REASONING: RELATED CONCEPTS}

When considering the act of caring, since the moment of data collection the learner performs apprehension of cues (conception) and makes choices (judgment). Judgment is understood as the flexible and discriminative ability to recognize relevant aspects (data) of an undefined clinical situation, interpreting its meaning and providing an appropriate response $\mathrm{e}^{(5)}$.

The learner has to use critical thinking to make a judgment. This involves a set of skills previously learned and attitudes necessary for the development of clinical reasoning ${ }^{(6)}$.
These skills can be divided into three categories: cognitive skills (analysis, application of standards, self-regulation, discrimination, information seeking, explanation, inference, interpretation, prediction and transformation of knowledge), behavioral skills (analysis, self-confidence, open-mindedness and systematization) and mental habits (understanding, confidence, creativity, curiosity, flexibility, intellectual integrity, intuition, perseverance, intellectual perspective and reflection) ${ }^{(7)}$.

The development of these skills is crucial for the development of the learner's clinical reasoning. Clinical reasoning is understood as the process of thinking and decision making integrated in the clinical practice of caring for health care consumers $^{(8,6)}$.

The steps of the clinical reasoning process, essential for the decision making, are represented in Figure 1.

Figure 1 - Thinking processes, based on the abilities for critical thinking, that composes the clinical reasoning, subsidizing the clinical decision making (diagnostic or therapeutic)

Therefore, clinical reasoning in nursing is a complex and dynamic mental process. It occurs in the identification of situations that demand nursing care and in the selection of actions necessary for such care, in order to reach the health outcomes under nursing responsibility ${ }^{(8)}$.

\section{CLINICAL REASONING: DEVELOPMENT}

Clinical reasoning is an essential function for health care. The performance of the professional depends on multiple factors, but its final outcome cannot be good if the thinking skills are deficient ${ }^{(9)}$.

The efficiency of health care is highly dependent on an adequate analysis and synthesis of clinical data and on the quality of the decisions involving risks and benefits of diagnostic tests and treatments ${ }^{(9)}$. 
The result of the clinical reasoning will guide the decision making, which may be diagnostic or therapeutic. It involves, therefore, the choice for a behavior, among one or more alternatives, with the intention of achieving a desired objective ${ }^{(10)}$.

Several factors may interfere in the decision-making process: theoretical knowledge, experience acquired in practice, judgment and reasoning, and good sense $\mathrm{e}^{(11)}$.

Clinical reasoning can be developed by different models: pattern recognition or inductive reasoning (comparison); decision tree or decision analysis (algorithm method for organizing knowledge); hypothetic-deductive reasoning, which involves generating preliminary hypotheses and processing information using logic to reformulate, accept or refute them; and exhaustion method, which searches the individual's clinical data, comparing them to known standards to determine the present diagnoses ${ }^{(12-13)}$.

The choice for a reasoning model by the learners or the ease of use of one model depends on the learner's previous skills and knowledge. Therefore, the educator must consider these aspects when presenting the possible models for the development of clinical reasoning to the student. For example, previous knowledge of combinatorial structures for problem solving, which involve partitions, permutations, combinations and Cartesian product, may favor a proper understanding of the problem and the respective decision making ${ }^{(14)}$.

Based on the literature considerations ${ }^{(14)}$, we present situations that exemplify these representations and which, in our view, are exercises that collaborate for the development of clinical reasoning:

- The head nurse encounters the following problem: three nurses ask for time off preference in the same holiday and he or she can accept only two of them, respecting first and second classification to grant time off. How many ways can he or she organize these two classifications of preferences?

- A given unit has four boxes of venous devices with different colors. There is an organizer with four compartments and I want to put each box in one of these compartments. How many different ways can I organize it?

- An adolescent was encouraged to eat two fruits a day; he or she likes five kinds of fruit. In how many ways can he or she associate these fruits?

- João can enter through three gates (A, B and C) to get to work in the hospital. He can leave through six different exits $(\mathrm{E}, \mathrm{F}, \mathrm{G}, \mathrm{H}, \mathrm{I}$ and J). How many ways can he get in and out of the hospital?

If previous experiences and knowledge are relevant to the development of reasoning, then a pertinent question is: which model of analysis and synthesis will be the most appropriate for the student to obtain a diagnosis in a clinical situation?

Depending on these skills and knowledge, we may come across students who prefer to use schemes or charts for data organization; others might prefer tables. Therefore, the reasoning process will be easier for some students when using the Conceptual Map ${ }^{(15)}$, while others will find the Risner Mod$\mathrm{el}^{(16)}$ an easier tool for the elaboration of the diagnosis.

Therefore, in order to teach how to develop clinical reasoning, the professor should use multiple strategies, since each learner is unique and uses different analysis and synthesis models.

\section{CLINICAL REASONING: TEACHING STRATEGIES}

The development of clinical reasoning for an appropriate practice is intrinsically related to the use of different teaching strategies. Several studies found in the literature identify the advantages and disadvantages of each strategy, as it was summarized in two literature reviews ${ }^{(17-18)}$.

In Crosseti et al. ${ }^{(17)}$ study addressing teaching strategies for critical thinking skills in nursing, the strategies listed are Questioning, Case Study, Online Teaching, Interactive Learning, Conceptual Map and Problem-Based Learning (PBL). Menezes et al. ${ }^{(18)}$ study presents teaching strategies related to development of critical thinking, clinical reasoning and decision making process. Among the strategies presented are mobile web-based learning technology, critical appraisal exercises, SAC learning tool (Structured Academic Controversy), mindmapping tool, learning activities based on the concept, the genogram, scenarios based on community health practices and clinical simulations of emergency situations.

In order to find updates on the subject, we searched the databases Cumulative Index to Nursing and Allied Health Literature (CINAHL) and PubMed, for the years from 2011 to 2016, using the keywords "nursing", "teaching" AND "clinical reasoning". We found 87 studies and selected 21 of them for reading. In these publications, besides the strategies already mentioned, were identified: Clinical simulation ${ }^{(19-21)}$, Teleconference ${ }^{(22)}$, Clicker ${ }^{(23)}$, Outcome Present Test ${ }^{(24)}$, Game series $^{(25)}$, Continuing education ${ }^{(26)}$ and Integrated learning ${ }^{(27)}$.

Other less disseminated strategies, such as vignette ${ }^{(28)}$ and scripts ${ }^{(29)}$, along with clinical simulations - a method that has received attention in several studies - were identified in the literature as relevant tools to develop clinical reasoning in health care professionals. In order to exemplify, we will highlight the strategies Clicker and Vignette.

Clicker questions refer to a multiple-choice electronic response system, which gradually increases the depth of critical thinking needed to identify correct answers. They can be used in several contexts, in order to introduce a subject or during the development of a theme ${ }^{(23)}$. Below, we may find a hypothetical example (Figure 2).

As questions arise, the answers are computed, some advantages of the use of clicker questions are: greater involvement in the class, as students' responses are anonymous they do not feel constrained to send their answers; greater attention of the participants; better preparation of students before class; discussion about the correct and incorrect answers. The disadvantages reported are the little time to think before answering and possible difficulties due to the discussion between right and wrong answers ${ }^{(23)}$. 
A.C.S.L. 11 months, female with pneumonia. Respiratory exam showed: Crackles and wheezes in right lung, cough for 2 days, short, occasional associated with fever and pain, 98\% O2 Sat in room. What is the nursing diagnosis?

1. Ineffective breathing pattern

2. Impaired gas exchange

3. Ineffective airway clearance

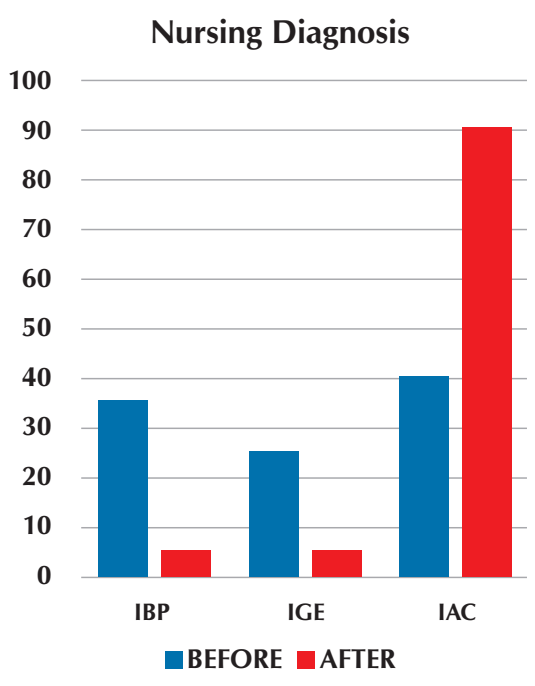

Figure 2 - Example of the Clicker strategy for teaching reasoning for nursing diagnosis

appropriate for his health problems. How do you think he would be in the long-term compared to other people in the community?

\section{CLINICAL REASONING: ASSESSMENT TOOLS}

Since several teaching strategies can be used to develop clinical reasoning, the question that arises is: how can students and nurses evaluate the development of clinical reasoning for an accurate practice?

In the literature review ${ }^{(18)}$ addressing the knowledge about clinical reasoning, decision making and critical thinking in nursing undergraduate teaching, some instruments to assess these aspects were presented, such as the Lasater Clinical Judgment Rubric that assesses clinical judgment;

A second strategy presented is the Vignette, which is a short and compact description of a real or fictional situation to attract attention, produce sensations and detect behavior, attitude and knowledge. It is structured in order to assess information about the perceptions, opinions or knowledge of the students regarding the phenomenon studied ${ }^{(30-33)}$.

The following is a hypothetical example of vignette and its respective questions, according to Ferreira et al. ${ }^{(28)}$ :

"José, 52, has had four days of the symptoms redness, edema, warm to touch and pain in the left leg, with ascending progression, associated with inappetence, fever and general health decline. Smoker (for 14 years/1 cigarette pack per day), two episodes of tuberculosis (one in youth and another one recently)".

1. Diagnostic knowledge: From the information given, what is wrong with José?

2. Professional Intervention: do you think José needs professional help?

3. Intervention by different people: If José were to seek one of the following professionals (list), would this help, hurt or neither?

4. Drug Interventions: If José were to take one of the medications (list), would this help, hurt, or neither?

5. Diverse interventions: If José were to do something of what is mentioned (list), would this help, hurt, or neither?

6. Prognosis with professional help: What would be the likely outcome if José had the kind of professional help you find most appropriate?

7. Prognosis without professional help: What would be the likely outcome if José had not had any professional help?

8. Performance in social situations: Suppose José had the kind of professional help you find most
Watson-Glaser Critical Thinking Appraisal - WGCTA, Critical Thinking Skills Test - CCTST, California Critical Thinking Disposition Inventory - CCTDI that assess critical thinking; and Spanish Test of Creative Intelligence - CREA e Thinking Styles Inventory - TSI that investigate associations between thinking styles and creativity presented by students and nurses. The authors argue that the future challenges for research related to clinical reasoning are to develop teaching and evaluation with theoretical consistency ${ }^{(18)}$.

In order to exemplify alternatives to meet this challenge, we will present the above mentioned Lasater Clinical Judgment Rubric $^{(34)}$ and, in addition, the Script Concordance Test ${ }^{(35)}$.

The Lasater Clinical Judgment Rubric (LCJR) is an observation assessment tool for the trajectory of the development of clinical judgment in nursing students. This tool, developed by Lasater ${ }^{(34)}$, presents 11 dimensions distributed in the four stages of Tanner's model of clinical judgment ${ }^{(36)}$. The students are classified according to their behaviors in each dimension.

The first stage "Noticing" involves three dimensions: focused observation; recognizing deviations from expected patterns; information seeking. The second stage "Interpreting" involves two dimensions: prioritizing data and making sense of data. The third stage "Responding" involves four dimensions: calmness; confident manner; clear communication; well-planned and flexible intervention; and being skillful. The fourth and final stage "Reflection" involves two dimensions: evaluation and self-analysis; and commitment to improvement ${ }^{(34)}$.

The LCJR tool was translated and adapted to the Brazilian culture by Nunes ${ }^{(37)}$. It presents the expected behaviors of the student for every stage and dimension, representing the levels of clinical judgment performance of the learner: exemplary, accomplished, developing or beginning. This assessment of the clinical reasoning process may be done either by the professor or through the student's self-assessment ${ }^{(38)}$. 
Another instrument that can be used to support the process of clinical reasoning is the Script Concordance Test. It is an assessment tool for clinical reasoning based on the Cognitive Psychology Script Theory ${ }^{(35)}$. This theory posits that when healthcare professionals face clinical problems, they organize knowledge (scripts) to understand the situation and make clinical decisions ${ }^{(35)}$.

These scripts are used daily in clinical practice, and are refined by experience ${ }^{(39)}$. They have considerably improved the evaluation system in a clinical context, since they allow the same evaluation for an unlimited number of students in a short time ${ }^{(40)}$.

This tool is based on the written presentation of clinical cases, followed by diagnostic or therapeutic decision-making options after the presentation of new information. The responses are presented in a Likert scale, showing the variability of the clinical reasoning process in a context of uncertainty ${ }^{(40-41)}$.

Going back to the example presented for the vignette strategy, it is possible to consider the use of the Script Concordance Test, based on the considerations of Kazour et al. ${ }^{(40)}$.

José, 52, has had four days of the symptoms redness, edema, warm to touch and pain in the left leg, with ascending progression, associated with inappetence, fever and general health decline. Smoker (14 years/1 cigarette pack/per day), two episodes of tuberculosis (one in youth and one recent.

Chart 1 - Use of script in clinical nursing practice

\begin{tabular}{|c|c|c|}
\hline $\begin{array}{l}\text { If you are } \\
\text { thinking of: }\end{array}$ & $\begin{array}{l}\text { And then you find } \\
\text { out: }\end{array}$ & This diagnosis: \\
\hline $\begin{array}{l}\text { 1. Ineffective } \\
\text { peripheral tissue } \\
\text { perfusion }\end{array}$ & $\begin{array}{l}\text { That the patient has } \\
\text { paresthesia }\end{array}$ & $\begin{array}{ccc}-2 & -1 & 0 \\
+1 & +2\end{array}$ \\
\hline $\begin{array}{l}\text { 2. Ineffective } \\
\text { breathing pattern }\end{array}$ & $\begin{array}{l}\text { He presented } \\
\text { hypercapnia, } \\
\text { hypoxia, cyanosis, } \\
\text { abnormal arterial pH }\end{array}$ & $\begin{array}{lll}-2 & -1 & 0 \\
+1 & +2\end{array}$ \\
\hline
\end{tabular}

Source: Example of test structure based on the reference of Kazour et al., ${ }^{(54)}$.

Note: -2: rejected hypothesis; -1: unlikely; 0 : no less, nor more likely; +1 : more likely; + 2: certainly/very certainly confirmed.

The vignette can also be used to support decisions or evaluations of interventions, in addition to diagnosis.

Finally, another instrument worth mentioning is the Nursing Diagnoses Accuracy Scale (NDAS). This scale is based on the model proposed by Lunney ${ }^{(42)}$, which didn't reach the same validity values in the study carried out in Brazil and, therefore, was adjusted for our culture ${ }^{(43)}$.

According to these authors, the accuracy of a nursing diagnosis is defined as "the judgment of an evaluator regarding the level of relevance, specificity and consistency of the cues available for the diagnosis". The evaluation of such items results in a final score that indicates the degree of accuracy of the diagnosis assessed (high, moderate or null) ${ }^{(43)}$.

It is important to emphasize that the choice for a diagnosis with high accuracy implies in the selection of the care plan (results and interventions) more appropriate to the context.
The use of the NDAS, a reliable and valid instrument, allows an improvement of the knowledge about the diagnostic process ${ }^{(43)}$.

An example of the application of the NDAS in a hypothetical situation:

Patient P.A, female, 35 years old, smoker and sedentary. Complains of abdominal pain, difficulty to evacuate for 7 days and because of this, cannot sleep for the past 5 days. Physical examination showed tiredness, abdominal distension, hypoactive sounds andpalpable abdominal mass. Vital signs: RR: 24mrpm; HR: 104bpm; BP: $110 \times 68$ mmHg; BT: $36.7^{\circ} \mathrm{C}$.
Nursing Diagnoses proposed for the situation
1: Constipation
2: Anxiety

After the diagnostic reasoning process, the student must evaluate if the diagnoses proposed are accurate, based on the NDAS score ${ }^{(43)}$. To evaluate the degree of accuracy, the student answers the questions to evaluate the cues, especially regarding relevance, specificity and consistency among them: Are there cues for this diagnosis? Is this cue necessary to indicate this diagnosis? Is this cue characteristic of the diagnosis? Is this cue consistent with the diagnosis? And finally, without awarding scores, would you state this diagnosis?

In the example, after computing the scores of each question, according to the instrument, the first hypothesis (ND: constipation) we would have the highest scores in the items relevance, specificity and consistency, with an accuracy degree of 13.5 points (high accuracy), confirming this diagnosis. The second ND hypothesis (Anxiety), in our view, would not be sustained given its low accuracy.

This instrument has been used not only in teaching but also in research, with potential to contribute to a higher precision of the clinical reasoning. Likewise, there is still a long way to stimulate the use of the instruments to support the evaluation of reasoning and the strategies for the construction of this thought process.

As a challenge, we reiterate Menezes et al. ${ }^{(18)}$ argument that there are few studies that favor the improvement of clinical reasoning including reflexive strategies, which seem to be more appropriate when thinking about clinical reasoning models that include psychosocial questions and emphasize nurses' standards and ethical-moral dilemmas ${ }^{(18)}$.

\section{FINAL CONSIDERATIONS}

The skills and abilities involved in clinical reasoning are intervening factors to determine the actions and decisions in the different stages of the nursing process.

Despite the contribution of the literature to strategies for teaching and evaluation of the clinical reasoning process, there is still a lack of knowledge about the subject and a need to test strategies, develop researches and construct new instruments appropriate to Brazilian culture.

Stimulating reasoning since an early age and clinical reasoning from the beginning of academic activities will contribute to having generations with higher performance in skills essential for good professional performance and decision making in daily life. 


\section{REFERENCES}

1. Harmon MM, Thompson C. Clinical reasoning in pre-licensure nursing students. Teach Learn Nurs[Internet]. 2015[cited 2016 Oct 02];10(2):63-70. Available from: http://www.jtln.org/article/S1557-3087(15)00002-5/abstract

2. USA. Department of Health and Human Services Administration for Children and Families Office of Head Start. Head Start early learning outcomes framework: ages birth to five[Internet]. 2015[cited 2016 Oct 02]. Available from: https://eclkc.ohs.acf.hhs.gov/ hslc/hs/sr/approach/pdf/ohs-framework.pdf

3. Lunney M. Pensamento crítico e diagnósticos de enfermagem: estudos de caso e análises. Porto Alegre: Artmed; 2003. p.265-8.

4. Lunney M. Pensamento crítico para o alcance de resultados positivos em saúde. Análise e estudos de caso em enfermagem. Porto Alegre: Artmed, 2011.

5. Balduino AFA, Mantovani MF, Lacerda MR. Nursing care plan for patients with chronic heart disease. Esc Anna Nery Rev Enferm[Internet]. 2009[cited 2016 Oct 02];13(2):342-51. Available from: http://www.scielo.br/pdf/ean/v13n2/v13n2a15.pdf

6. Cerullo JASB, Cruz DALM. Clinical Reasoning and Critical Thinking. Rev Latino-Am. Enfermagem [Internet]. 2010[cited 2016 Oct 02];18(1):[06 telas]. Available from: http://www.scielo.br/pdf/rlae/v18n1/19.pdf

7. Crossetti MGO, Goes MGO. Habilidades de pensamento critico no processo diagnóstico de enfermagem. In: T.H.Herdman (org) PRONANDA: Programa de Atualização em Diagnósticos de Enfermagem. 1ed. Porto Alegre: Artmed Panamericana. 2016;4(1):9-34.

8. Higgs J, Jones M. Clinical reasoning in the health professions. Oxford: Butterworth Heinemann; 1995.

9. Réa-Neto A. Raciocínio clínico: o processo de decisão diagnóstica e terapêutica. Rev Ass Med Brasil. 1998;44(4):301-11.

10. Ciampone MHT et al. Tomada de Decisão em enfermagem. 3. ed. São Paulo: EPU, 1991. p. 191-205.

11. Lopez M. O Processo Diagnóstico nas decisões clínicas. Ciência, arte e ética. Rio de Janeiro: Revinter; 2001.

12. Biselli PJ, Atta JÁ. Diagnóstico sindrômico. Rev Med (São Paulo). 2005; 84(3-4):95-101.

13. Roberti A, Roberti MRF, Pereira ERS, Porto CC, Costa NMSC. Development of clinical reasoning in an undergraduate medical program at a Brazilian university. São Paulo Med J[Internet]. 2016[cited 2016 Oct 02];134(2):110-5. Available from: DOI: 10.1590/1516-3180.2015.00080108

14. Azevedo J, Borba RESR. Combinatória: a construção de árvores de possibilidades por alunos dos anos iniciais com e sem uso de softwares. ALEXANDRIA. Rev Educ Ciênc Tecnol[Internet]. 2013[cited 2016 Oct 02];6(2):113-40. Available from: https:// periodicos.ufsc.br/index.php/alexandria/article/viewFile/37957/28985

15. Bittencourt GKGD, Schaurich D, Marini M, Crossetti MGO. Application of concept map for the identification of nursing diagnosis. Rev Bras Enf[Internet]. 2011[cited 2016 Oct 02];4(5):963-7. Available from: http://www.scielo.br/pdf/reben/v64n5/a25v64n5.pdf

16. Risner PB. Nursing diagnosis: diagnostic sistements. In: Christensen, P. J; Kenney, J.W. ed. Nursing Process: application of conceptual modes. $4^{\text {a }}$ ed. St. Louis: Mosby; 1996.

17. Crossetti MDGO, Bittencourt GKGD, Schaurich D, Tanccini T. Estratégias de ensino das habilidades do pensamento crítico na enfermagem. Rev Gaúcha Enferm[Internet]. 2009[cited 2016 Oct 02];30(4): 732-41. Available from: http://www.scielo.br/pdf/ rgenf/v30n4/a21v30n4.pdf

18. Menezes SSC, Corrêa CG, Silva RCG, Cruz DAML. Clinical reasoning in undergraduate nursing education: a scoping review. Rev Esc Enferm USP[Internet]. 2015[cited 2016 Oct 02];49(6):1037-44. Available from: http://www.scielo.br/pdf/reeusp/v49n6/00806234-reeusp-49-06-1037.pdf

19. Forsberg E, Ziegert K, Hult H, Fors U. Clinical reasoning in nursing, a think-aloud study using virtual patients - A base for an innovative assessment. Nurse Educ Today[Internet]. 2014[cited 2016 Oct 02];34(4):538-42. Available from: http://www.ncbi.nlm. nih.gov/pubmed/23938093

20. Gibbs J, Trotta D, Overbeck A. Human patient simulation versus case study: Which teaching strategy is more effective in teaching nursing care for the hypoglycemic patient? Teaching and Learning in Nursing[Internet]. 2014[cited 2016 Oct 02]9:59-63. Available from: http://www.jtln.org/article/S1557-3087(14)00003-1/pdf

21. Mahoney AED, Hancock LE, Lorianni-Cimbak A, Curley MAQ. Using high-fidelity simulation to bridge clinical and classroom learning in undergraduate pediatric nursing. Nurse Educ Today[Internet]. 2013[cited 2016 Oct 02];33:648-54.Available from: http://www.nurseeducationtoday.com/article/S0260-6917(12)00007-X/pdf

22. Gazarian PK, Pennington M. Clinical Teleconferencing: bringing the patient to the classroom. Nurs Forum[Internet]. 2012[cited 2016 Oct 02];47(4).Available from: http://onlinelibrary.wiley.com/doi/10.1111/j.1744-6198.2012.00279.x/pdf

23. Russell JS, McWilliams M, Chasen L, Farley J. Using Clickers for Clinical Reasoning and Problem Solving. Nurse Educator[Internet]. 2011[cited 2016 Oct 02];36(1):3-15. Available from: https://blogs.commons.georgetown.edu/clickers_cop/ files/00006223-201101000-00008.pdf 
24. Bland AR, Bartlett R, Rossen EK, Kautz DD, Carnevale T, Benfield S. Implementation and testing of the OPT Model as a teaching strategy in an undergraduate psychiatric nursing course. Nurs Educ Perspec[Internet]. 2009[cited 2016 Oct 02];30:14-21. Available from: http://www.ncbi.nlm.nih.gov/pubmed/19331034

25. Dariel OJP, Raby T, Ravaut F, Rothan-Tondeur M. Developing the Serious Games potential in nursing education. Nurse Educ Today[Internet]. 2013[cited 2016 Oct 02];33:1569-75. Available from: http://www.nurseeducationtoday.com/article/S0260-6917(12)00411-X/pdf

26. Goudreau J, Pepin J, Larue C, Dubois S, Descôteaux R, Lavoie P, Dumont K. A competency-based approach to nurses' continuing education for clinical reasoning and leadership through reflective practice in a care situation. Nurse Educ Pract[Internet]. 2015[cited 2016 Oct 02];15:572-8. Available from: http://dx.doi.org/10.1016/j.nepr.2015.10.013

27. Duff B. A theoretically informed education program designed specifically for acute surgical nurses. Nurse Educ Today[Internet]. 2012[cited 2016 Oct 02];32:73-8. Available from: http://dx.doi.org/10.1016/j.nedt.2012.03.012

28. Ferreira FN, Fernandino DC, Souza GRM, Ibrahim TF, Fukino ASL, Araújo NC et al. Evaluation of Attitudes toward Schizophrenic Patients among Health Students. Rev Bras Educ Méd[Internet]. 2015[cited 2016 Oct 02];39(4):542-57. Available from: http://www. scielo.br/pdf/rbem/v39n4/1981-5271-rbem-39-4-0542.pdf

29. Charlin B, Tardif J, Boshuizen HPA. Scripts and Medical Diagnostic Knowledge: Theory and Applications for Clinical Reasoning Instruction and Research. Academic Medicine. 2000; 75(2).

30. Gould D. Using vignettes to collect data for nursing research studies: how valid are the findings? J Clin Nurs[Internet]. 1996[cited 2016 Oct 02];5(4):207-12. Available from: http://dx.doi.org/10.1111/j.1365-2702.1996.tb00253.x

31. Alexander CS, Becker HJ. The use of vignettes in survey research. Public Opin Q[Internet]. 1978[cited 2016 Oct 02];42:93-104. Available from: http://dx.doi.org/10.1086/268432

32. Flaskerud JH. Use of vignettes to elicit responses toward broad concepts. Nurs Res. 1979; 28(4):210-2.

33. Polit DF, Hungler BP. Fundamentos de pesquisa em enfermagem: avaliação de evidências para a prática de enfermagem. $7^{\mathrm{a}}$ ed. Porto Alegre: Artmed; 2011

34. Lasater K. The impact of high-fidelity simulation on the development of clinical judgment in nursing students: An exploratory study. 2005. [Dissertation]. Portland State University, Oregon, USA; 2005. 244f.

35. Charlin B, Roy L, Brailovsky C, Goulet F, van der Vleuten C. The script concordance test: a tool to assess the reflective clinician. Teach Learn Med[Internet]. 2000[cited 2016 Oct 02];12:189-95. Available from: http://dx.doi.org/10.1207/S15328015TLM1204_5

36. Tanner CA. Thinking like a nurse: a research based model of clinical judgment in nursing. J Nurs Educ. 2006; 45(6): $204-11$.

37. Nunes JGP. Julgamento clínico e raciocínio diagnóstico de estudantes de enfermagem em simulação clínica de alta-fidelidade. [Tese]. Escola de Enfermagem de Ribeirão Preto, Universidade de São Paulo, 2016.

38. Miraglia R, Asselin ME. The lasater clinical judgment rubric as a framework to enhance clinical judgment in novice and experienced nurses. J Nurses Prof Dev [Internet]. 2015[cited 2016 Oct 02];31(5): 284-91. Available from: http://dx.doi.org/10.1097/ NND.0000000000000209

39. Nouh T, Boutros M, Gagnon R, Reid S, Leslie K, Pace D, et al. The script concordance test as a measure of clinical reasoning: a national validation study. The American Journal of Surgery [Internet]. 2012 [cited 2016 Oct 02]; 203: 530-534. Available from: http://dx.doi.org/10.1016/j.amjsurg.2011.11.006

40. Kazour F, Richa S, Zoghbi M, El-Hage W, Haddad FG. Using the script concordance test to evaluate clinical reasoning skills in psychiatry. Acad Psychiatry[Internet]. 2017 [cited 2017 Mar 02]; 41(1):86-90. Available from: http://dx.doi.org/10.1007/ s40596-016-0539-6

41. Piovezan RD, Custódio O, Cendoroglo MS, Batista NA. Teste de concordância de scripts: uma proposta para a avaliação do raciocínio clínico em contextos de incerteza. Rev Bras Educ Med[Internet]. 2010[cited 2016 Oct 02];34(1):5-12. Available from: http://dx.doi.org/10.1590/S0100-55022010000100002

42. Lunney M. Accuracy of nursing diagnosis: concept development. Nurs Diagn. 1990;1(1):12-7.

43. Matos FGOA, Cruz DALM. Development of an instrument to evaluate diagnosis accuracy. Rev Esc Enferm USP [Internet]. 2009[cited 2016 Oct 02];43(spe):1088-97. Available from: http://www.scielo.br/pdf/reeusp/v43nspe/en_a13v43ns.pdf 